\title{
Array-based profiling of the differential methylation status of CpG islands in hepatocellular carcinoma cell lines
}

\author{
BIN-BIN LIU, DAN ZHENG, YIN-KUN LIU, XIAO-NAN KANG, LU SUN, \\ KUN GUO, RUI-XIA SUN, JIE CHEN and YAN ZHAO \\ Liver Cancer Institute, Zhongshan Hospital of Fudan University, Shanghai 200032, P.R. China
}

Received February 8, 2010; Accepted June 26, 2010

DOI: 10.3892/ol_00000143

\begin{abstract}
Alterations in the DNA methylation status particularly in $\mathrm{CpG}$ islands are involved in the initiation and progression of many types of human cancer. A number of DNA methylation alterations have been reported in hepatocellular carcinoma (HCC). However, a systematic analysis is required to elucidate the relationship between differential DNA methylation status and the characteristics and progression of HCC. In the present study, a global analysis of DNA methylation using a human CpG-island $12 \mathrm{~K}$ array was performed on a number of $\mathrm{HCC}$ cell lines of different origin and metastatic potential. Based on a standard methylation alteration ratio of $\geq 2$ or $\leq 0.5,58 \mathrm{CpG}$ island sites and 66 tumor-related genes upstream, downstream or within were identified. This study showed a series of $\mathrm{CpG}$ island methylation alterations in the HCC cell lines. The expression of various oncogenes, tumor suppressor genes and other key genes were up- or downregulated, respectively, resulting in $\mathrm{CpG}$ island hypomethylation or hypermethylation accordingly. To conclude, a foundation has been provided for screening $\mathrm{CpG}$ island methylation profiles as HCC biological markers.
\end{abstract}

\section{Introduction}

DNA methylation plays an essential role in various physiological processes such as mammalian development, genomic imprinting, $\mathrm{X}$ chromosome inactivation and aging (1). Alterations in the DNA methylation status were also found to be involved in the initiation and progression of human cancer. Among these alterations, the aberrant methylation of $\mathrm{CpG}$ islands located in the promoter regions or first exons of various genes is the best-categorized epigenetic change (2). By silencing tumor suppressor genes or activating oncogenes, epigenetic modifications can affect many important cellular processes, such as cell cycle control, DNA repair and apoptosis. Previously, the aberrant methylation status of specific

Correspondence to: Dr Yin-Kun Liu, Liver Cancer Institute, Zhongshan Hospital of Fudan University, Shanghai 200032, P.R. China E-mail: liu.yinkun@zs-hospital.sh.cn

Key words: hepatocellular carcinoma, methylation, $\mathrm{CpG}$ island, microarray, methylation-specific PCR genes was linked to the pathogenesis of various types of cancer, and tumor-specific methylation changes were established as prognostic markers in numerous tumor entities (3). Unlike genetic modifications, such as mutations or genomic imbalances, epigenetic changes are potentially reversible, making these changes particularly important therapeutic targets in cancer and other diseases (4).

In recent years, different techniques have been developed for the genome-wide screening of CGI methylation status. Included is differential methylation hybridization (DMH) which is a high-throughput DNA methylation screening tool that utilizes methylation-sensitive restriction enzymes to profile-methylated fragments by hybridizing them to a $\mathrm{CpG}$ island microarray. This method was introduced by Huang and coworkers in 1999 (5), further developed and has since been widely used (6).

Human hepatocellular carcinoma (HCC) is the sixth most common type of cancer worldwide and is the second cause of cancer-related death in China. The main obstacles to improving the outcome of HCC patients is the high frequency of recurrence and metastasis. Various genetic and epigenetic abnormalities in HCC have been identified, suggesting a multi-step nature of hepatocarcinogenesis (7). A number of genetic and epigenetic alterations have been noted in HCC (8). However, each alteration appears to be implicated in a limited fraction of HCC. Thus, the systematic analysis of the genetic and epigenetic alterations underlying the origin and evolution of HCC has attracted the interest of scientists worldwide (9-13). The present study employed the DMH method to analyze the differential methylation status of $12 \mathrm{~K} \mathrm{CpG}$ islands in a number of HCC cell lines. Tumor cell lines are commonly used as experimental tools in cancer research as such cell lines exhibit a number of the same epigenetic and genetic aberrations that are noted in primary carcinomas. The HCC cell lines selected in this study are of different origin, and among these, the MHCC97 series cell lines have the same genetic backgrounds but exhibit different metastatic potential. These characteristics render them useful for screening epigenetic alterations underlying the mechanism of metastasis.

\section{Materials and methods}

Cell culture. Human HCC cell lines HepG2, Hep3B, PLC/ $\mathrm{RPF} / 5$ and human liver cell line L02 were purchased from 


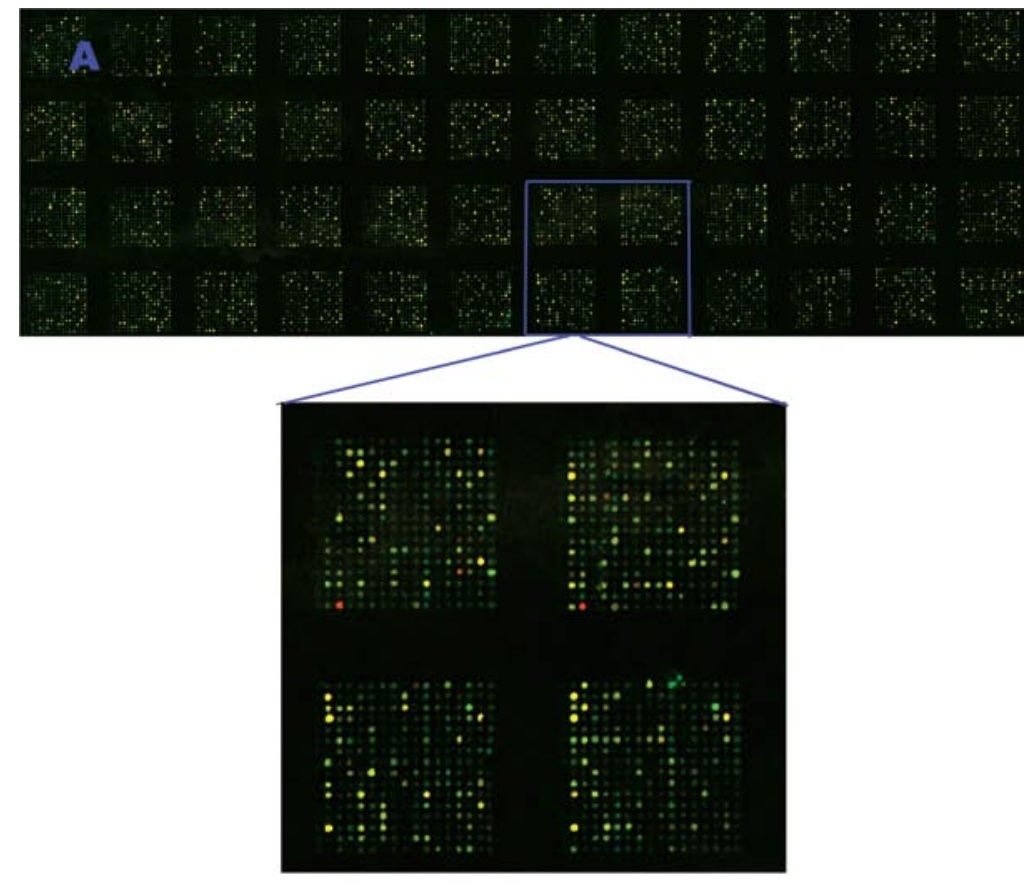

B

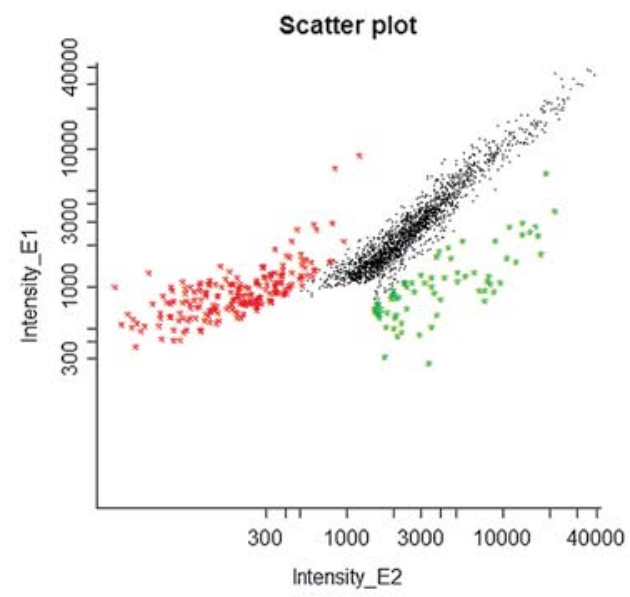

Figure 1. Representative results of differential methylation hybridization. (A) The DNA amplicons of HCC and control cell lines were fluorescently labeled with $\mathrm{Cy} 5$ and $\mathrm{Cy} 3$, respectively, and cohybridized to a UHN 12K human CpG island microarray. The hybridization output was measured in intensities of the two fluorescence reporters. The inset is an expanded view of the box area. The yellow spots indicate no methylation differences between the tumor and normal genomes. The red spots show hypermethylated $\mathrm{CpG}$ island loci present in the tumor genome. The green spots indicate loss of methylation in the tumor genome. (B) Scatter diagram of the hybridization results of the two samples. Each point in the scatter diagram represented the hybridization signal of corresponding $\mathrm{CpG}$ islands in the chip. The results show obvious differentiation of $\mathrm{CpG}$ island methylation between $\mathrm{HCC}$ and the control cell lines.

American Type Culture Collection (ATCC). SMMC-7721 and BEL-7402 cell lines were purchased from the Institute of Biochemistry and Cell Biology, Chinese Academy of Sciences. The MHCC97-H, MHCC97-L, HCCLM3 and HCCLM6 cell lines, which have similar genetic backgrounds but different metastatic potential, were established at our institute. Cells were cultured in high glucose DMEM supplemented with $10 \%$ fetal bovine serum and penicillin-streptomycin under humidified conditions in $5 \% \mathrm{CO}_{2}$.

$C p G$ island microarray hybridization and data analysis. Total DNA of the cells was extracted using the DNeasy
Kit (Qiagen, Germany). The $\mathrm{CpG}$ island array containing $12,192 \mathrm{CpG}$ island clones was purchased from Canada UHN Microarray Center. Hybridization and signal scanning were conducted by the Capitalbio Corporation of Beijing, China. The hybridization images were analyzed using GenePix Pro 4.0 software (Axon Instruments). The data were smoothed using the Lowess method which was subsequently followed by cluster analysis. The ratios of $\mathrm{Cy} 5$ to $\mathrm{Cy} 3$ were calculated for each location on each microarray. A ratio $(\mathrm{Cy} 5 / \mathrm{Cy} 3)$ of $\geq 2$ or $\leq 0.5$ was considered to indicate differential methylation loci. Additionally, the hybridization output was measured in intensities of the two fluorescence reporters (Fig. 1). 
Table I. Hypermethylated $\mathrm{CpG}$ islands and associated genes in the HCC cell lines.

\begin{tabular}{lll}
\hline ID of CpG island & \multicolumn{2}{c}{ Associated genes } \\
\hline UHNhscpg0011158 & PPP2CA & (upstream) \\
& CDKL3 & (downstream) \\
UHNhscpg0009735 & SRPK1 & (downstream) \\
UHNhscpg0004629 & CP110 & (downstream) \\
UHNhscpg0004752 & GJB2 & (within) \\
& GJB6 & (downstream) \\
& GJA3 & (upstream) \\
UHNhscpg0004878 & BCL2 & (downstream) \\
UHNhscpg0002925 & SMAD7 & (downstream) \\
UHNhscpg0008205 & IRS4 & (upstream) \\
UHNhscpg0008444 & FGFR2 & (downstream) \\
UHNhscpg0003663 & LHX5 & (within) \\
UHNhscpg0007707 & PIK3CB & (upstream) \\
UHNhscpg0004799 & VRK2 & (upstream) \\
& BCL11A & (downstream) \\
UHNhscpg0009327 & FANCL & (within) \\
UHNhscpg0008203 & TM4SF5 & (upstream) \\
UHNhscpg0000104 & PIM1 & (upstream) \\
UHNhscpg0008444 & BCL11A & (upstream) \\
UHNhscpg0005488 & BRWD2 & (upstream) \\
UHNhscpg0008226 & PDCD4 & (downstream) \\
UHNhscpg0004835 & ST5 & (downstream) \\
& CBX4 & (within) \\
UHNhscpg0003460 & CBX8 & (upstream) \\
UHNhscpg0009830 & CDH18 & (upstream) \\
UHNhscpg0003252 & EPHB4 & (upstream) \\
UHNhscpg0004910 & ATF2 & (within) \\
UHNhscpg0004957 & HNF4G & (downstream) \\
UHNhscpg0004834 & LRP1 & (upstream) \\
& GSTA4 & (upstream) \\
UHNhscpg0004596 & ICK & (within) \\
UHNhscpg0003693 & RYK & (upstream) \\
UHNhscpg0001904 & FZD3 & (upstream) \\
UHNhscpg0004926 & SPRY3 & (downstream) \\
UHNhscpg0011292 & MAPK8IP3 & (downstream) \\
UHNhscpg0003315 & SLIT2 & (downstream) \\
\hline & HAND2 & (within) \\
\hline
\end{tabular}

Analysis of the genes associated with the differentially methylated $\mathrm{CpG}$ islands. The official website (http://data. microarrays.ca/cpg/) of the UHN human $\mathrm{CpG}$ island database was accessed, and the upstream, within and downstream genes associated with significant $\mathrm{CpG}$ islands were located according to their ID numbers. The references were searched and the associated genes were classified according to their function.

Bisulfite treatment of DNA- and methylation-specific $P C R$. The bisulfite treatment of DNA was adapted from Frommer et al with slight modifications (14). Briefly, $2 \mu \mathrm{g}$
3B LM3 LM6 G2 PLC 74027721 L-02 97-H 97-L

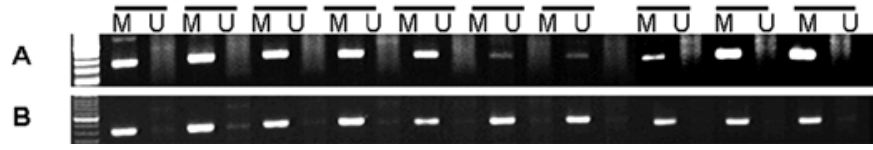

Figure 2. MSP results of two randomly selected $\mathrm{CpG}$ islands: (A) UHNhscpg0009830 and (B) UHNhscpg0004835. M and U are the methylated and unmethylated PCR products, respectively.

DNA was diluted with $50 \mu \mathrm{l}$ distilled $\mathrm{H}_{2} \mathrm{O}$, and $5.5 \mu 13 \mathrm{M}$ $\mathrm{NaOH}$ was added. Incubation was carried out at $37^{\circ} \mathrm{C}$ for 15 min to create single-stranded DNA. Freshly prepared $10 \mathrm{mM}$ hydroquinone (30 $\mu \mathrm{l}$ ) (Sigma) and $520 \mu \mathrm{l} 3 \mathrm{M}$ sodium bisulfite (pH 5.0) (Sigma, S-8890) were added to each tube. After thorough mixing, a layer of $200 \mu \mathrm{l}$ mineral oil was added. Incubation was carried out at $50^{\circ} \mathrm{C}$ for $16 \mathrm{~h}$, and the oil was then removed. The modified DNA was purified using the Promega Wizard Cleanup DNA kit and precipitated at $-20^{\circ} \mathrm{C}$ overnight. Centrifugation was performed at $12,000 \mathrm{rpm}$ for $30 \mathrm{~min}$ at $4^{\circ} \mathrm{C}$. The supernatant was removed using a pipette, and the precipitate was washed with $500 \mu 175 \%$ ethanol and centrifuged at $12,000 \mathrm{rpm}$ for $5 \mathrm{~min}$ at $4^{\circ} \mathrm{C}$, and repeated once. The supernatant was then removed using a pipette, and the dried pellet was resuspended in $30 \mu \mathrm{l}$ distilled water and preserved at $-20^{\circ} \mathrm{C}$ until use.

Two differential $\mathrm{CpG}$ islands were randomly selected and methylation-specific PCR (MSP) was performed to verify the microarray results. PCR primers were designed using MethPrimer (http://www.ucsf.edu/urogene/methprimer/index1. html). The PCR program involved an initial denaturation at $95^{\circ} \mathrm{C}$ for $10 \mathrm{~min}$, followed by 35 cycles of amplification as follows: denaturation at $95^{\circ} \mathrm{C}$ for $30 \mathrm{sec}$, annealing at $48^{\circ} \mathrm{C}$ for $30 \mathrm{sec}$, and extension at $72^{\circ} \mathrm{C}$ for $30 \mathrm{sec}$, with an additional extension at $72^{\circ} \mathrm{C}$ for $4 \mathrm{~min}$. The PCR products were analyzed with agarose gel electrophoresis and DNA sequencing.

\section{Results}

The DNA amplicons of different HCC cell lines, with Chang's liver cell line as a control, were fluorescently labeled with $\mathrm{Cy} 5$ and $\mathrm{Cy} 3$, respectively, and cohybridized to a UHN $12 \mathrm{~K}$ human $\mathrm{CpG}$ island microarray. Findings showed obvious differentiation of $\mathrm{CpG}$ island methylation between $\mathrm{HCC}$ and the control cell lines (Fig. 1). After further cluster analysis, we detected 58 differentially methylated $\mathrm{CpG}$ islands and 66 related tumor-associated genes that exhibited a similar trend in alteration ( 6 of the 9 cell lines had an identical trend) in the $9 \mathrm{HCC}$ cell lines compared with the normal control. Among these, $37 \mathrm{CpG}$ islands showed hypermethylation (Table I) and 29 showed hypomethylation (Table II). In addition, when compared with the MHCC97-L cells, 16 differentially methylated $\mathrm{CpG}$ islands that may be associated with metastatic potential were detected in the MHCC97-H cells (24 related genes) (Table III).

Two randomly selected differential $\mathrm{CpG}$ islands were further analyzed with MSP and DNA sequencing in the HCC cell lines. The results showed a high correlation with the microarray results (Fig. 2). The methylation status of a number of other significant $\mathrm{CpG}$ islands and expression of the associ- 
Table II. Hypomethylated $\mathrm{CpG}$ islands and associated genes in the HCC cell lines.

ID

\begin{tabular}{lll}
\hline UHNhscpg0006172 & SEC13L1 & $\begin{array}{l}\text { (upstream) } \\
\text { (upstream) }\end{array}$ \\
UHNhscpg0002224 & PRC1 & (within) \\
UHNhscpg0008081 & RAE1 & (upstream) \\
UHNhscpg0007289 & HNF4G & (upstream) \\
UHNhscpg0002482 & CDCA7L & (within) \\
UHNhscpg0006623 & EPHA7 & (upstream) \\
& MAP3K7 & (within) \\
UHNhscpg0005013 & PECAM1 & (upstream) \\
UHNhscpg0003756 & PA2G4 & (upstream) \\
UHNhscpg0002482 & CDCA7L & (downstream) \\
UHNhscpg0001077 & EGR3 & (downstream) \\
UHNhscpg0002020 & NAB2 & (upstream) \\
UHNhscpg0007707 & PIK3CB & (upstream) \\
UHNhscpg0002943 & PPIAL4 & (upstream) \\
UHNhscpg0009335 & MAF & (downstream) \\
UHNhscpg0010477 & ID2 278 & (within) \\
UHNhscpg0005863 & ZNF278) \\
UHNhscpg0001373 & MAPRE2 & (downstream) \\
UHNhscpg0005140 & PTPNS1 & (downstream) \\
UHNhscpg0000025 & VCL & (downstream) \\
UHNhscpg0002244 & DPYSL2 & (within) \\
UHNhscpg0004830 & THBS1 & (within) \\
UHNhscpg0001262 & NR5A2 & (within) \\
UHNhscpg0009002 & DYNLRB2 & (downstream) \\
UHNhscpg0002482 & RAPGEF5 & (downstream) \\
UHNhscpg0004867 & RIN3 & (downstream) \\
UHNhscpg0009717 & IRS4 & (upstream) \\
UHNhscpg0008232 & & \\
UHNhscpg0001274 & ROBO3 & (within) \\
UHNhscpg0005005 & SV2B & (within) \\
\hline & & \\
\hline
\end{tabular}

Gene function determined from GeneCards at http://www.genecards.org.

ated gene were also detected with MSP and RT-PCR with the aim of analyzing the association of gene expression with DNA methylation status.

\section{Discussion}

Tumorigenesis and tumor metastasis are complex, multi-step processes involving genetic and epigenetic alterations. The roles of epigenetic alterations, particularly that of DNA methylation status, in the progression and metastasis of $\mathrm{HCC}$ recently attracted the interest of numerous investigators. Due to HCC sensitivity to the influence of external factors as opposed to the DNA sequence, alterations in the DNA methylation status may be the earliest event in tumorigenesis and metastasis. The reversible characteristics of the DNA methylation status make it attractive in tumor intervention $(15,16)$.

The present study employed the differential methylation hybridization method to assess the alteration of $\mathrm{CpG}$ island methylation in a number of HCC cell lines. The results showed that alteration of the $\mathrm{CpG}$ island methylation is a common event in HCC cell lines of different origin and metastatic potential. The genes associated with these $\mathrm{CpG}$ islands included prooncogenes and oncogenes, tumor suppressor genes, apoptosis genes, proliferation and cell cycle regulatory genes, as well as tumor angiogenesis- and immuno-escape-associated genes. The concept of a $\mathrm{CpG}$ island methylator phenotype (CIMP) was first proposed by Issa et al (17) and is currently widely accepted as a novel type of biomarker employed to classify different types of cancer or cancers of different stages $(17,18)$. The present array-based study profiled the $\mathrm{CpG}$ island methylation status in HCC cell lines of different origin and metastatic potential. The potential of an HCC-specific CIMP was also noted, particularly since numerous liver cell-specific genes were involved in the differences. As a 'marker pattern', CIMP has a marked superiority in reflecting the clinical complexity and variability of cancer versus the use of a single marker.

Recently, molecular alterations of various signaling pathways (e.g., Wnt//-catenin, Ras/Raf/MEK/ERK and PI3K/ $\mathrm{Akt} / \mathrm{mTOR}$ ) were identified in liver carcinogenesis, providing novel molecular targets for new treatment modalities $(19,20)$. Sorafenib, the first FDA-approved drug for advanced liver cancer, is a multi-kinase inhibitor that targets the Ras/Raf signaling pathway (21). A DNA methylation mechanism was involved in the modification of these signaling pathways. Hypermethylation in the promoters of the Wnt pathway associated with adenomatous polyposis coli and E-cadherin was recently reported (22-24). Based on our data, a number of other members involved in the Wnt pathway also displayed alterations in the methylation status in associated $\mathrm{CpG}$ islands. These members included frizzled 3 (FZD3), receptor

Table III. Genes associated with the differentially methylated CpG islands in the MHCC97H and MHCC97L cell lines ${ }^{\text {a }}$

\section{Cell line}

Associated genes

97H/97L

With hypermethylation in the $\mathrm{CpG}$ island

BCL11A, VRK2, FANCL, GJB2, GJB6, GJA3, CBX4, CBX8, ICK, ATF2, LRP1, GSTA4, TM4SF5

With hypomethylation in the CpG island

THBS1, ZNF278, IRS4, HNF4G, CDCA7L, RAPGEF5, PPIAL4, PA2G4, PIK3CB, MAF, DYNLRB2 
tyrosine kinase (RYK), c-myc, ID2 and MAPRE2, which showed hypomethylation in the associated $\mathrm{CpG}$ islands in the HCC cell lines compared with the control cells, suggesting that DNA methylation is a crucial mechanism that adjusts the Wnt signaling pathway to favor HCC. On the other hand, alterations in the methylation of factors involved in the Ras/Raf pathway were also found in this study, including RAPGEF5, which serves as a Ras activator and Ras and Rab interactor 3 (RIN3).

Numerous other important $\mathrm{CpG}$ islands and the associated genes previously investigated in other solid tumors were also analyzed and verified in our data. EPHB4 is a member of the Eph family of receptor tyrosine kinases. Its interaction with the ligand ephrinB2 contributes to the growth of various types of tumors and can influence the clinical outcome of cancer patients (25-27). According to our data, the EPHB4-associated $\mathrm{CpG}$ island was hypermethylated, and the expression of the EPHB4 gene was downregulated in the HCC cell lines. The role of the EPHB4 gene in HCC progression warrants further investigation. Slit and Roundabout (Robo) were first identified as guidance molecules for neurons and leukocytes (28). More recently, their roles were expanded to include the mediation of angiogenesis, heart morphogenesis and tumor metastasis (29-32). In vertebrates three Slit (Slit1, Slit2 and Slit3) and four Robo (Robo1, Robo2, Robo3/Rig-1 and Robo4/Magic Robo) genes have been identified (33). Certain members of the Slit/Robo signaling pathway also showed frequent alterations of the $\mathrm{CpG}$ island methylation status in our data. Further investigations of the methylation status of $\mathrm{CpG}$ islands in the promoter region and mRNA expression levels of Slit1, Slit2, Slit3, Robol and Robo3 were subsequently carried out in several HCC cell lines of different metastatic ability (data not shown). A number of differences in the methylation and expression of the genes were detected in different HCC cell lines. In particular, Slit2 expression may be associated with metastatic potential, indicating a potential involvement of Slit/ Robo in the progression or metastasis of HCC.

Various genes of unknown function also appeared in the list due to regular alterations between HCC and the control cell lines. The potential roles of these genes in the progression and metastasis of HCC warrant further investigation.

In conclusion, the differentially methylated $\mathrm{CpG}$ islands and associated genes screened by microarray in the HCC cell lines in this study have provided the foundation for understanding HCC-specific CIMP and for developing potential biomarkers of significance for the prognosis and metastasis of HCC. Furthermore, the reversible characteristic of DNA methylation status offers suitable targets for the interference therapy of HCC.

\section{Acknowledgements}

This study was supported by a grant from the National Nature Science Foundation of China (no. 30500484) and Shanghai Nature Science Foundation (no. 04ZR14025).

\section{References}

1. Scarano MI, Strazzullo M, Matarazzo MR and D'Esposito M: DNA methylation 40 years later: Its role in human health and disease. J Cell Physiol 204: 21-35, 2005.
2. Jones PA and Baylin SB: The fundamental role of epigenetic events in cancer. Nat Rev Genet 3: 415-428, 2002.

3. Esteller M: Epigenetics in cancer. N Engl J Med 358: 1148-1159, 2008.

4. Pfister S, Schlaeger C, Mendrzyk F, et al: Array-based profiling of reference-independent methylation status (aPRIMES) identifies frequent promoter methylation and consecutive downregulation of ZIC2 in pediatric medulloblastoma. Nucleic Acids Res 35: e51, 2007.

5. Huang TH, Perry MR and Laux DE: Methylation profiling of $\mathrm{CpG}$ islands in human breast cancer cells. Hum Mol Genet 8: 459-470, 1999.

6. Yan PS, Potter D, Deatherage DE, Huang TH and Lin S: Differential methylation hybridization: profiling DNA methylation with a high-density $\mathrm{CpG}$ island microarray. Methods Mol Biol 507: 89-106, 2009.

7. Herath NI, Leggett BA and MacDonald GA: Review of genetic and epigenetic alterations in hepatocarcinogenesis. JGastroenterol Hepatol 21: 15-21, 2006.

8. Park IY, Sohn BH, Yu E, Suh DJ, Chung YH, Lee JH and Surzycki SJ: Aberrant epigenetic modifications in hepatocarcinogenesis induced by hepatitis B virus X protein. Gastroenterology 132: 1476-1494, 2007.

9. Wang L, Wang WL, Zhang Y, Guo SP, Zhang J and Li QL: Epigenetic and genetic alterations of PTEN in hepatocellular carcinoma. Hepatol Res 37: 389-396, 2007.

10. Calvisi DF, Ladu S, Gorden A, et al: Mechanistic and prognostic significance of aberrant methylation in the molecular pathogenesis of human hepatocellular carcinoma. J Clin Invest 117: 2713-2722, 2007

11. Calvisi DF, Ladu S, Gorden A, et al: Molecular pathogenesis of human hepatocellular carcinoma: Mechanistic and prognostic significance of aberrant methylation. AACR Meeting Abstracts 2006: 763a, 2006.

12. Thorgeirsson SS and Grisham JW: Molecular pathogenesis of human hepatocellular carcinoma. Nat Genet 31: 339-346, 2002.

13. Pei Y, Zhang T, Renault V and Zhang X: An overview of hepatocellular carcinoma study by omics-based methods. Acta Biochim Biophys Sin 41: 1-15, 2009.

14. Frommer M, McDonald LE, Millar DS, et al: A genomic sequencing protocol that yields a positive display of 5-methylcytosine residues in individual DNA strands. Proc Natl Acad Sci USA 89: 1827-1831, 1992

15. Humeniuk R, Mishra PJ, Bertino JR and Banerjee D: Molecular targets for epigenetic therapy of cancer. Curr Pharm Biotechnol 10: 161-165, 2009.

16. Schneider-Stock R and Ocker M: Epigenetic therapy in cancer: Molecular background and clinical development of histone deacetylase and DNA methyltransferase inhibitors. IDrugs 10: 557-561, 2007.

17. Issa JP: CpG island methylator phenotype in cancer. Nat Rev Cancer 4: 988-993, 2004.

18. Shen L, Catalano PJ, Benson AB III, O'Dwyer P, Hamilton SR and Issa JP: Association between DNA methylation and shortened survival in patients with advanced colorectal cancer treated with 5-fluorouracil-based chemotherapy. Clin Cancer Res 13: 6093-6098, 2007.

19. Tommasi S, Pinto R, Pilato B and Paradiso A: Molecular pathways and related target therapies in liver carcinoma. Curr Pharm Des 13: 3279-3287, 2007.

20. Pang RW and Poon RT: From molecular biology to targeted therapies for hepatocellular carcinoma: the future is now. Oncology 72 (Suppl 1): 30-44, 2007.

21. Gollob JA, Wilhelm S, Carter C and Kelley SL: Role of Raf kinase in cancer: therapeutic potential of targeting the Raf/ MEK/ERK signal transduction pathway. Semin Oncol 33: 392-406, 2006.

22. Prasad CP, Mirza S, Sharma G, et al: Epigenetic alterations of $\mathrm{CDH} 1$ and APC genes: relationship with activation of Wnt/betacatenin pathway in invasive ductal carcinoma of breast. Life Sci 83: 318-325, 2008

23. Banno K, Yanokura M, Susumu N, et al: Relationship of the aberrant DNA hypermethylation of cancer-related genes with carcinogenesis of endometrial cancer. Oncol Rep 16: 1189-1196, 2006.

24. Supic G, Kozomara R, Brankovic-Magic M, Jovic N and Magic Z: Gene hypermethylation in tumor tissue of advanced oral squamous cell carcinoma patients. Oral Oncol 45: 1051-1057, 2009. 
25. Kumar SR, Singh J, Xia G, et al: Receptor tyrosine kinase Ephb4 is a survival factor in breast cancer. Am J Pathol 169: 279-293, 2006.

26. Noren NK, Lu M, Freeman AL, Koolpe M and Pasquale EB: Interplay between Ephb4 on tumor cells and vascular Ephrin-B2 regulates tumor growth. Proc Natl Acad Sci USA 101: 5583-5588, 2004.

27. Berclaz G, Karamitopoulou E, Mazzucchelli L, et al: Activation of the receptor protein tyrosine kinase Ephb4 in endometrial hyperplasia and endometrial carcinoma. Ann Oncol 14: 220-226, 2003.

28. Bashaw GJ and Goodman CS: Chimeric axon guidance receptors: the cytoplasmic domains of slit and netrin receptors specify attraction versus repulsion. Cell 97: 917-926, 1999.
29. Stella MC, Trusolino L and Comoglio PM: The Slit/Robo system suppresses hepatocyte growth factor-dependent invasion and morphogenesis. Mol Biol Cell 20: 642-657, 2009.

30. Liu ZJ and Herlyn M: Slit-Robo: neuronal guides signal in tumor angiogenesis. Cancer Cell 4: 1-2, 2003.

31. Marlow R, Strickland P, Lee JS, et al: SLITs suppress tumor growth in vivo by silencing Sdf1/Cxcr4 within breast epithelium. Cancer Res 68: 7819-7827, 2008.

32. Wang B, Xiao Y, Ding BB, et al: Induction of tumor angiogenesis by Slit-Robo signaling and inhibition of cancer growth by blocking Robo activity. Cancer Cell 4: 19-29, 2003.

33. Hohenester E: Structural insight into Slit-Robo signalling. Biochem Soc Trans 36: 251-256, 2008. 